\title{
PUMA (Puma concolor) PREDATING SHEEP IN UBERLÂNDIA, BRAZIL: PHYSICAL INJURIES, STRESS AND MYOPATHY
}

\author{
PREDAÇÃO DE OVELHAS POR ONÇA-PARDA (Puma concolor) EM \\ UBERLÂNDIA, BRASIL: LESÕES MACROSCÓPICAS, ESTRESSE E MIOPATIA
}

\author{
Thaís de Almeida MOREIRA ${ }^{1}$; Gilberto de Lima MACEDO JÚNIOR ${ }^{2}$; \\ Rafael Rocha de SOUZA ${ }^{1}$; Márcio de Barros BANDARRA ${ }^{2}$; Matias Pablo Juan SZABÓ ${ }^{2}$ \\ 1. Pós-graduando do curso de Ciências Veterinárias da Faculdade de Medicina Veterinária da Universidade Federal de Uberlândia, \\ Uberlândia, MG, Brasil; 2. Docente da Faculdade de Medicina Veterinária da Universidade Federal de Uberlândia, Uberlândia, MG, \\ Brasil.szabo@ufu.br
}

\begin{abstract}
Puma (Puma concolor) is in Brazil among the major species involved in human-wildlife conflicts, primarily due to the predation of sheep and goats in farms. A puma might kill from one to several animals in a single predation episode, and free-ranging flocks of goats and sheep are usually affected. These attacks are rarely witnessed and direct observation of predation is rare. We herein report three predation episodes and the cause of death of sheep kept inside paddocks in a farm located besides a major town of Minas Gerais State, Brazil. Death of 31 animals was attributed to a puma as determined by circumstantial evidence, necropsy of 16 animals, laboratory findings and direct observation of the predator at the occurrence site. However, death of only eight animals was caused by traumatic injury mainly at the cervical region. The remaining animals lacked lethal traumatic injuries and post mortem examination indicated circulatory collapse (congestion of internal organs). Two surviving animals had a great increase in creatinine phosphokinase blood levels and thus death of remaining animals was attributed to stress and myopathy caused by fear and chasing of sheep trapped inside paddocks. Measures taken after the third predation episode (illumination of paddocks, pasture height control, vegetation clearance around the paddocks and closure of animals in stalls at night) prevented further attacks.
\end{abstract}

KEYWORDS: Predation. Ovine. Stress. Cause of death. Necropsy.

\section{INTRODUCTION}

Human-wildlife conflicts have diversified and are increasing in Brazil, many times related to increase of animal populations adapted to anthropogenic sites and/or moving from rural to suburban or urban areas (FERRAZ et al., 2003; MARCHINI et al., 2015). This seems the case of the puma (Puma concolor) that may survive at degraded natural areas at apparently high population densities (MIOTTO et al., 2014). The high behavioral plasticity of Puma at anthropogenic sites can be attributed, partially at least, to the use of resources from both natural and modified environment (MAGIOLI et al., 2014). Thus, pumas, once restricted to remote natural or rural areas, have been increasingly reported in the press for their appearances in unsuspected places and for collisions with vehicles in populated places (MARCHINI et al., 2015).

Puma predation of sheep and goats and occasionally cattle, is a major cause of conflicts (MAZZOLLI, et al., 2002; VIDOLIN et al., 2004; PALMEIRA et al., 2008). Predation events involve from one or two animals to more than 20 in a few days (MAZZOLLI et al., 2002; GRAIPEL et al., 2004). Since most of the times free-ranging flocks of goats and sheep are affected, attacks of pumas are rarely witnessed and direct observation of predation episodes are rare. Under such circumstances determination of predation as the cause of death is many times circumstantial: aberrant livestock behavior, young or small livestock that simply disappear, predator signs (WADE; BOWNS, 2012).

Pumas kill their preys by biting the top of the neck, head or throat region inflicting injuries to Central Nervous System (spinal cord or encephalus) (WADE; BOWNS, 2012; MAZZOLLI, 2009/2013). We herein report three puma predation episodes of sheep at a farm neighboring a major Brazilian town characterized by biting trauma in a few animals and by fear-triggered stress and myopathy on several others.

\section{CASE REPORT}

Episodes herein described occurred in the Capim Branco farm of the Federal University of Uberlândia, Uberlândia, Minas Gerais State, southeast Brazil. Uberlândia $\left(18^{0} 55^{\prime} \mathrm{S} ; 48^{0} 16^{\prime} \mathrm{W}\right)$ is a major Brazilian town with over 600,000 inhabitants and located within the Cerrado Biome, a savannah. This farm has 367 hectares, is located at the outskirts of the city and is cut by the Uberabinha 
river. This river has a riparian forest along its course within the farm and Cerrado patches, both forestall and grassy phytophysiognomies of the Biome, are scattered within the property. The farm is devoted to crop production (soybean and corn) and breeds cattle for meat, pigs, sheep and goat. Sheep of Santa Inês, Dorper as well as mixed breeds are maintained for teaching and experimental purposes (nutrition and animal husbandry) and animal numbers vary from 100 to 160 along the year. These animals are kept in 24 paddocks (Figure 1) or inside a stable. Each paddock has approximately $800 \mathrm{~m}^{2}$ is fenced with $1.20 \mathrm{~m}$ high woven wires (Tela Campestre $\AA$ ) with an additional $20 \mathrm{~cm}$ high barbed wire at the outside perimeter of paddocks. Grass of paddocks is Urochloa brizantha (marandú cultivar) and was over $50 \mathrm{~cm}$ of height at the time of the death episodes. Paddocks are flanked by forest patch that is connected to the riparian forest. Distance between forest and nearest paddock is around 10 meters.

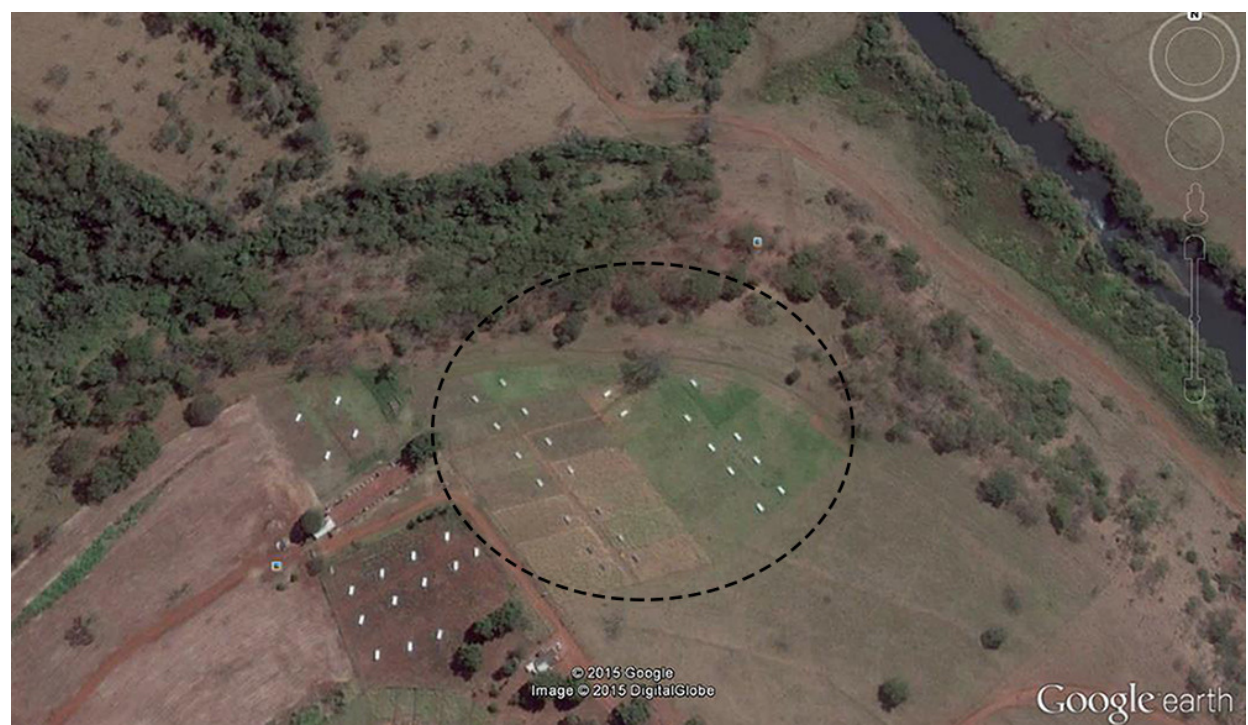

Figure 1. Satelite photo of the Capim Branco farm. Sheep paddocks close to forest patch are encircled.

Three sudden death episodes of sheep occurred in the farm in 2014 and 2015. The first occurred in $10^{\text {th }}$ of December 2014 and 17 animals were found dead, in the second, in $19^{\text {th }}$ of January of 2015 , six animals died and the third on the $27^{\text {th }}$ of May 2015, when eight animals died. All sheep were females and many in late pregnancy (over 100 days). Overall, sixteen sheep from the three episodes were taken to the Veterinary Pathology sector of the Federal University of Uberlândia for necropsy. Tissue samples were collected, processed according to routine histological procedures and stained with Hematoxylin-eosin. Within the affected paddocks, seven animals survived the first death episode and from these two exhibited linear skin lesions on the dorsum. From these sheep, blood was collected 12 to 18 hours after the predation episode aiming evaluation of muscle and kidney function. Routine hematological and biochemical procedures were conducted for red and white cell counts and to determine creatinine, urea nitrogen, aspartate aminotransferase (AST) and creatinine phosphokinase (CK) blood levels.

Death of animals occurred in two or three paddocks, those closest to the forest patch. A few of the dead animals were found hidden under straw. Warped fences, ovine hair on wires, overthrown plant protecting cages (used for nutrition experiments) and footprints by the fences indicated an outburst of animal movement inside the paddocks. Carnivore footprints, suggestive of puma, were observed inside paddocks and one day after the first death episode and an adult puma (Puma concolor) was seen by one of the employees at night $(08: 30 \mathrm{pm})$ in ambush position close to the paddocks.

All examined animal were females in reproductive phase, 18 to 48 months old and many exhibited prominent post-mortem alterations even though death occurred less than 24 hours before. Main gross lesions found on animals are listed in Table 1 and shown in Figure 2. 
Table 1. Main gross findings during the necropsy of 16 ovine found dead at puma predation site, Uberlândia, Brazil, 2014 and 2015. Number of examined animals in relation to overall found dead is presented between brackets.

\begin{tabular}{|c|c|c|c|c|}
\hline \multirow[t]{2}{*}{ Findings } & $\begin{array}{c}\text { Episode 1 } \\
(13 / 17)\end{array}$ & $\begin{array}{c}\text { Episode } 2 \\
(1 / 6)\end{array}$ & $\begin{array}{c}\text { Episode } 3 \\
(2 / 8)\end{array}$ & $\begin{array}{l}\text { Total } \\
(16 / 31)\end{array}$ \\
\hline & \multicolumn{4}{|c|}{ Number of animals with lesion } \\
\hline Skin: puncture wounds & 5 & - & 2 & 8 \\
\hline $\begin{array}{l}\text { Skin: linear knife-like wounds and associated } \\
\text { subcutaneous hemorrhages }\end{array}$ & 4 & 1 & 1 & 5 \\
\hline Evisceration & 2 & - & 1 & 3 \\
\hline Tracheal perforation/laceration & 4 & - & 2 & 6 \\
\hline Epistaxis & 3 & - & - & 3 \\
\hline Foam in the trachea & 5 & 1 & - & 6 \\
\hline Lung congestion & 11 & 1 & 2 & 14 \\
\hline Epicardic petechiae & 8 & & 1 & 9 \\
\hline Liver congestion & 3 & 1 & 1 & 5 \\
\hline Renal congestion & 8 & 1 & 1 & 10 \\
\hline Encephalic congestion & 5 & 1 & 2 & 8 \\
\hline Presence of fetus & 7 & 1 & 1 & 9 \\
\hline
\end{tabular}

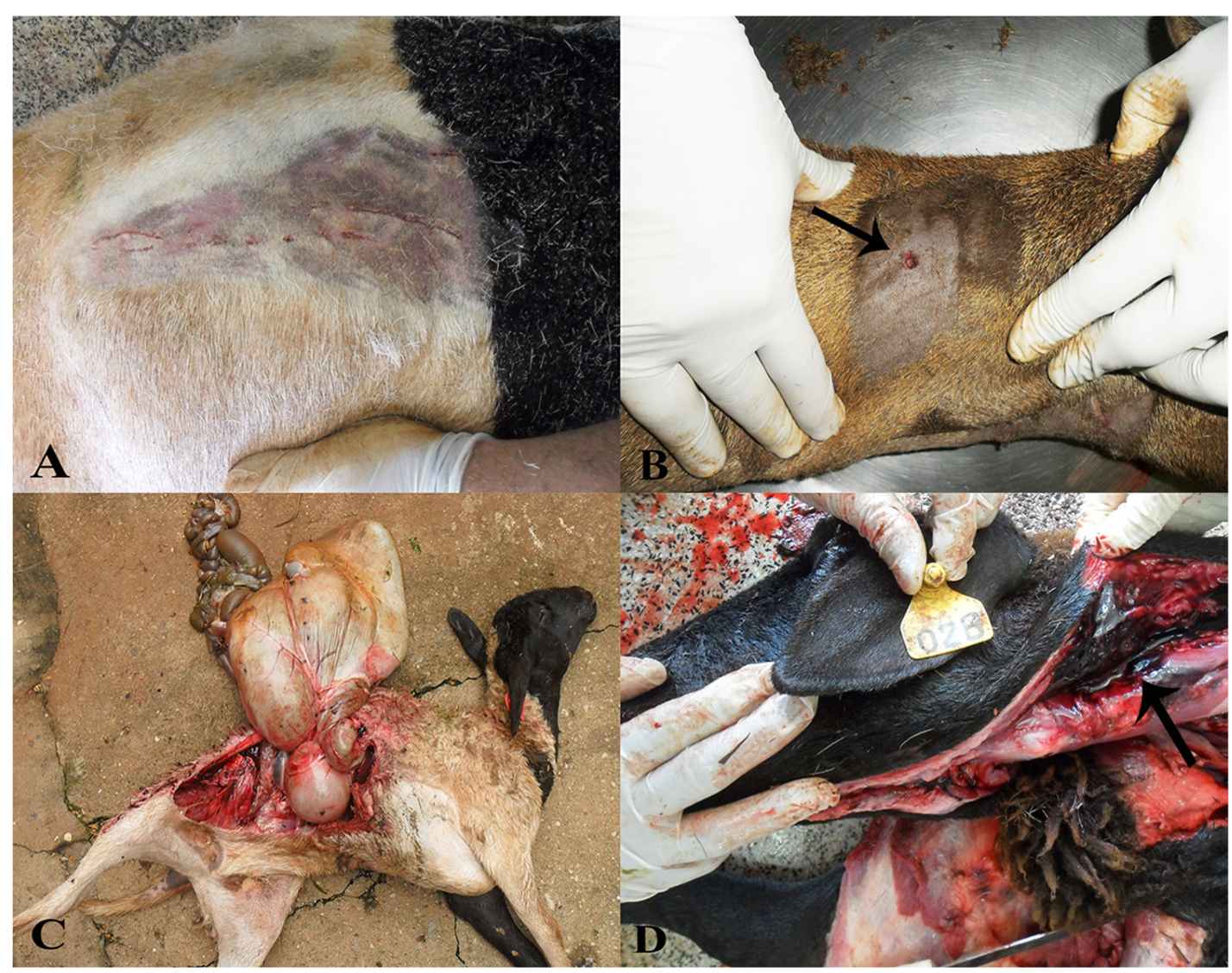

Figure 2. Sheep wounds from puma predation episodes; A) linear lumbar knife-like wounds; B) dorsal puncture wounds on the neck (arrow); C) Abdominal evisceration and decreased amount of blood; D) Tracheal perforation and hemorrhage (arrow).

Lethal predation lesions were observed in eight animals. From these three were eviscerated (two abdominal and one thoracic) and six had severe cervical injuries (puncture skin wounds associated with extensive subcutaneous and muscle hemorrhages and tracheal collapse by perforations/laceration). At the same time three animals did not exhibit any trauma lesion and five animals exhibited only minor non-lethal subcutaneous and skin lesions (small hemorrhages, linear, knife-like skin wounds) on various sites of the body surface (abdominal, thoracic, lumbar, 
submandibular, hind legs). Other major gross alterations observed in several animals included congestion of organs (lungs, brain and liver) tracheal foam and epicardic petechiae. Findings unrelated to predation included parasitic nodules on intestinal wall, and one or two fetuses in several animals. Microscopic findings confirmed severe congestion of organs, edema and emphysema of lungs and, in a few instances, prominent autolysis.

Blood cell counts of both animals were within normal range, except for a slight absolute neutrophilia $\left(8,904\right.$ cells $/ \mathrm{mm}^{3}$ - normal range 4006,000 cells $\left./ \mathrm{mm}^{3}\right)$ and leukocytosis $(15,900$ cells $/ \mathrm{mm}^{3}$ - normal range $4,000-12,000$ cells $\left./ \mathrm{mm}^{3}\right)$ in one of the animals and a slight neutrophilia $(7,416$ cells $/ \mathrm{mm}^{3}$ ) in the other. Both animals exhibited a several fold increase in creatinine phosphokinase blood levels; one animal with 1,309 U/L and the other with $272.1 \mathrm{U} / \mathrm{L}$ (reference value for the species - from 0 to 40 U/L- KANEKO et al., 1997). Other biochemical parameters were within normal host species range.

Death of 31 sheep from 100 adult animals as reported here is a major impact on production and reinforce the tendency for increasing human-wild animal conflicts in Brazil. Puma footprints within the paddocks, direct observation of a puma, dead animals hidden under straw as well as necropsy showed that sheep death was caused or related to predation. However, from the animals that underwent necropsy, death of only half was caused by predation injuries, three did not exhibit any trauma lesion and five animals exhibited only minor non-lethal ones.

Most (75\%) of the lethal injuries were found in the cervical region around the throat with extensive hemorrhage, perforation and/or laceration of trachea. Very likely, these animals were held by their throat and had a respiratory distress as indicated by lung edema (foam in the trachea). Evisceration was observed in three animals, with rupture of abdominal skin and muscles or partial lack of ribs, but blood clots were observed in only one of these. In fact, a greater quantity of blood patches and clots would be expected respectively, in the paddocks and in eviscerated animals. In this regard, it can be supposed that the puma licked blood, a behavior related to abundance of felled prey and driven by nutritional purposes (GRAIPEL et al., 2004).

Death of animals without lethal wounds was initially puzzling. However, observation of affected paddocks indicated that sheep in fear run inside paddocks. Indeed, a several fold increase in blood muscle enzyme levels (creatinine phosphokinase) from two surviving animals and that were undeniably chased (claw scratches on their dorsum) was detected. Such enzyme is a marker of muscle injury, blood levels reach a plateau 6-12 hour after the injury, fade away in one or two days and may be caused by work overload (ALLISON, 2015). The very high levels achieved by animals suggest a skeletal muscle injury but concomitant injury to cardiac muscle cannot be ruled out. Neutrophilia observed in these animals that remained alive is, a much less specific alteration; nevertheless, it may occur in animals submitted to exercise, excited and/or stressed (WEISER, 2015) as was the case herein reported.

Most animals displayed prominent postmortem alterations if one considers that necropsy occurred within 24 hours. In fact, such alterations were enhanced by the heat generated and exhaustion of energy (MYERS et al., 2012) in animals that were chased and stressed and hot summer temperatures in the two first events. Pregnancy, particularly two fetuses was also shown to increase ovine temperature (MACEDO JÚNIOR, 2008) and may have contributed to heat generation. Such alterations precluded trustful histopathological analysis in many cases. Nonetheless, severe congestion of liver, kidney, brain and lung as well as lung edema were confirmed by microscopy. Congestion of organs even at animals without physical injuries indicates that blood circulation collapse (shock) occurred in animals, probably due to heart muscle failure (MOSIER, 2012).

Taken previously discussed observations together, we accredit death of half of the animals to myopathy by work overload after running in fear within paddocks and stress caused by the predator. Under such circumstances, paddock behaved as a trap; it precluded sheep from running away to attain a safe and comforting distance. This situation is, in several aspects, similar to acute capture myopathy of wild animals. In this myopathy (reviewed by Carramenha and Carregaro, 2012) work overload and stress causes muscle hypoxia and acidosis, death of muscle fibers, hyperpotassemia and consequent ventricular fibrillation responsible for heart failure and therefore organ congestion. Muscle necrosis is a prominent feature of such syndrome, but we did not detect it in microscopy. Most probably, death was so acute that microscopic features had no time to develop. Furthermore, post mortem alterations overshadowed minor changes. Thus, CK enzyme increase of surviving animals was the main indicator of such occurrence.

Broadly, puma predation episodes herein described displayed many previously reported 
aspects. Sheep among several other domestic animal species from farm were predated reinforcing that, among livestock, it is the favorite prey of puma in Brazil (MAZZOLLI, et al., 2002; VIDOLIN et al., 2004; PALMEIRA et al., 2008). Events were associated with environment that favored predation; puma was able to undertake an unnoticed approach since a forest patch connected to a riparian forest was close to paddocks. Location is dark at night and there were no dogs that could have disturbed/frightened the predator. However, events also presented new features; predation did not occur in free-ranging flocks at distant sites but in paddocks very close to a human settlement and death of half of animals was not caused by biting injuries but rather by stress and related myopathy.

Measures taken after the third predation episode (illumination of paddocks, pasture height control, vegetation clearance around the paddocks and closure of animals in stalls at night) prevented further attacks until now, but longer observation period of their efficacy is needed. Nevertheless, close surveillance of predation episodes in the future is mandatory to determine if our observations were a rare event or an increasing tendency in wildlifehuman conflicts.

RESUMO: A onça-parda (Puma concolor) é uma das principais espécies relacionadas a conflitos entre humanos e animais selvagens no Brasil, principalmente devido predação de ovinos e caprinos em fazendas. Este felino selvagem pode matar de um a vários animais em um único episódio de predação, sendo geralmente, cabras e ovelhas criados extensivamente os mais afetados. Esses ataques raramente são testemunhados e por isso a observação direta da predação também é rara. Neste trabalho são relatados três episódios de predação e causa mortis de ovinos mantidos em piquetes em uma fazenda vizinha à Uberlândia, Minas Gerais, Brasil. A morte de 31 animais foi atribuída a uma onça-parda, conforme provas circunstanciais, exame necroscópico de 16 animais, achados laboratoriais e a observação direta do predador no local da ocorrência. Entretanto, a morte de apenas oito animais foi causada por lesão traumática, principalmente na região cervical. Os demais não apresentaram lesões traumáticas letais e nestes o exame post-mortem indicou colapso circulatório (congestão dos órgãos internos). Dois animais sobreviventes apresentaram acentuado aumento dos níveis sanguíneos de creatinina fosfoquinase, permitindo assim atribuir a morte dos demais animais ao estresse e miopatia provocadas pelo medo e perseguição das ovelhas dentro dos piquetes. Após o terceiro episódio de predação medidas preventivas foram adotadas e a iluminação dos piquetes, o controle da altura do capim nos piquetes, a redução da vegetação ao redor dos piquetes e a manutenção dos animais em baias fechadas durante a noite impediram novos episódios, pelo menos até o momento.

PALAVRAS-CHAVE: Predação. Ovinos. Estresse. Causa da morte. Necropsia.

\section{REFERENCES}

ALLISON, R. W. Detecção Laboratorial das lesões musculares. In: THRALL, M. A.; WEISER, G.; ALLISON, R. W.; CAMPBELL, T. W. (Eds). Hematologia e Bioquímica Clínica Veterinária. São Paulo: Roca LTDA, 2 ed., 2015. p. 412-415.

CARRAMENHA, C. P.; CARREGARO, A. B. Estresse e morte súbita em medicina veterinária. Revisão a convite. Ars Vet, Univ. de São Paulo, Jaboticabal, v. 28, n. 2, p. 90-99, jun. 2012.

FERRAZ, K. M. P. M. B.; LECHEVALIER, M. A.; COUTO, H. T. Z.; VERDADE, L. M. Damage caused by capybaras in a corn field. Sci. Agric., Piracicaba, v. 60, n. 1, p. 191-194, Jan./Feb. 2003.

GRAIPEL, M. E.; MAZZOLLI, M.; GHIZONI JUNIOR, I. R. Selvageria ou carência nutricional? Ciência Hoje, Santa Catarina, v. 35, n. 209, p. 62-65, out. 2004.

KANEKO, Jerry. J.; HARVEY, John. W.; BRUSS, Michael. L. Clinical Biochemistry of Domestic Animals. 5. ed., San Diego: Academic Press, 1997, 932 p.

MACEDO JÚNIOR, Gilberto de Lima. Exigências nutricionais de ovelhas gestantes da raça Santa Inês. 2008. 291 f. Dissertação (Doutorado em Zootecnia). Escola de Veterinária, Universidade Federal de Minas Gerais, Belo Horizonte, 2008. 
MAGIOLI, M.; MOREIRA, M. Z.; FERRAZ, K. M. B.; MIOTTO, R. A.; DE CAMARGO, P. B.; RODRIGUES, M. G.; CANHOTO, M. C. S.; SETZ, E. F. Stable Isotope Evidence of Puma concolor (Felidae) Feeding Patterns in Agricultural Landscapes in Southeastern Brazil. Biotropica, v. 46, n. 4, p. 461-460, jul. 2014. https://doi.org/10.1111/btp.12115

MARCHINI, S.; CRAWSHAW, J. R. P. G. Human-Wildlife Conflicts in Brazil: A Fast-Growing Issue. Hum. Dimens. Wildl, v. 20, n. 4, p. 323-328, may. 2015.

MAZZOLLI, M. Mountain lion Puma concolor attacks on a maned wolf Chrysocyon brachyurus and a domestic dog in a forestry system. Mastozool. Neotrop., Mendoza, v. 16, n. 2, p. 465-470, sep. 2009. https://doi.org/10.1016/S0006-3207(01)00178-1

MAZZOLLI, M.; GRAIPEL, M. E.; DUNSTONE, N. Mountain lion depredation in southern Brazil. Biol. Cons., v. 105, n. 1, p. 43-51, jul. 2002.

MAZZOLLI, M. Lethal biting behaviour of pumas (Carnivora, Felidae) interpreted from fractured skull of prey. Neotrop. Biol. Conserv., São Leopoldo, v. 8, n. 1, p. 63-66, jan/apr. 2013.

MIOTTO, R. A.; CERVINI, M.; KAJIN, M.; BEGOTTI, R. A.; GALETTI, J. R. P. M. Estimating puma (Puma concolor) population size in a human disturbed landscape in southeastern Brazil based on DNA markrecapture data, Oryx, Cambridge, v. 48, n. 2, p. 250-257, feb. 2014.

https://doi.org/10.1017/S0030605312000841

MOSIER, D. A. Vascular disorders and thrombosis. In: ZACHARY J. F., MCGAVIN, M. D. (Eds). Pathologic basis of Veterinary Disease. 6. ed., St Louis: Missouri, 2012. p. 63-99.

MYERS, R. K.; MCGAVIN, M. D.; ZACHARY, J. F. Cellular adaptation, injury and death: morphologic, bichemical and genetic basis. In: ZACHARY, J. F.; MCGAVIN, M. D. (Eds). Pathologic basis of Veterinary Disease. 5. ed. St Louis: Missouri, 2012. p. 29-30.

PALMEIRA, F. B. L.; CRAWSHAW, P. G. J. R.; HADDAD, C. M.; FERRAZ, K. M. P. M. B.; VERDADE, L. M. Cattle depredation by puma (Puma concolor) and jaguar (Panthera onca) in Northerh Goiás, Centralwestern Brazil. Biol. Cons., v. 141, p. 118-125, jan. 2008. https://doi.org/10.1016/j.biocon.2007.09.015

VIDOLIN, G. P.; MOURA-BRITTO, M.; BRAGA, F. G.; CABEÇAS-FILHO, A. Avaliação da predação a animais domésticos por felinos de grande porte no Estado do Paraná: implicações eestratégias conservacionistas. Cad. biodivers., Paraná, v. 4, n. 2, p. 50-58, dez. 2004.

WADE, D. A.; BOWNS, J. E. Predator Damage Identification. In: VANTASSEL SM. (Ed.). The Wildlife Damage Inspection Handbook. 3. ed., Wildlife Control Consultant, Lincoln: Nebraska, 2012.

WEISER, G. Interpretação da Resposta Leucocitária na Doença. In: THRALL M. A.; WEISER, G.; ALLISON, R.W.; CAMPBELL, T. W. (Eds). Hematologia e Bioquímica Clínica Veterinária. 2. ed., São Paulo: Roca LTDA, 2015. p. 412-415. 